\title{
Implementasi Digital Public Relations Pada Label Musik Demajors Dalam Mempublikasikan Album
}

\author{
Yos Horta Meliala, Rama Adipoetra, Riana Murti \\ Email: bangyos366@yahoo.com
}

Fakultas Ilmu Komunikasi Univ. Prof. Dr. Moestopo (Beragama)

\begin{abstract}
ABSTRAK
Penelitian ini bertujuan untuk mengetahui Implementasi digital Public Relations pada label music Demajors dalam mempublikasikan album kepada khalayak. Metodologi dalam penelitian ini menggunakan konsep public relations, digital public relations dengan pendekatan kualitatif, paradigma yang digunakan post positivisme serta pengumpulan data menggunakan wawancara mendalam, studi kepustakaan dan dokumentasi. Sebagai label music independent Demajors dalam hal ini divisi Promotion \& Media Relations berhasil menyampaikan pesan ke khalayak dengan menggunakan media sosial (new media) sehingga mampu bersaing dengan label mainstream. Kegiatan publikasi dilakukan dengan merujuk pada segmentasi musik yang sesuai dengan karakter musiknya. Hasilnya menunjukkan bahwa digital public relations menjadi tool yang tepat untuk mempublikasikan album kepada khlayak yang sekaligus menjadi pembeda dengan label musik independen yang ada di Indonesia.
\end{abstract}

Kata Kunci: implementasi, digital public relations, demajors

\begin{abstract}
This study aims to find out how the implementation of digital public relations implementation on the music label Demajors in publishing albums to the public. The methodology in this research uses the concept of public relations, digital public relations with a qualitative approach, the paradigm used in post positivism and data collection using in-depth interviews, literature study and documentation. As an independent music label Demajors in this case the Promotion \& Media Relations division managed to deliver a message to the public by using social media (new media) so that it can compete with mainstream labels. Publication activities carried out by referring to the segmentation of music in accordance with the character of the music. The results show that digital public relations is the right tool to publish albums to the public, which is at the same time a differentiator with independent music labels in Indonesia.
\end{abstract}

Key Words: Implementation, Digital Public Relations, Demajors

\section{PENDAHULUAN}

Perkembangan teknologi ke arah serba digital saat ini semakin pesat. Pada era digital seperti ini, manusia secara umum memiliki gaya hidup baru yang tidak bisa dilepaskan dari perangkat yang serba elektronik. Teknologi menjadi alat yang mampu membantu sebagian besar kebutuhan manusia. Teknologi telah dapat digunakan oleh manusia untuk mempermudah melakukan apapun tugas dan pekerjaan. Peran penting teknologi inilah yang membawa peradaban manusia memasuki era digital. Manusia cenderung melakukan aktivitas yang tidak dapat dipisahkan dari komputer, laptop, tab, dan smartphone. Kecenderungan manusia untuk selalu berinteraksi melalui komputer, smartphone, melalui internet dapat disebut sebagai gaya hidup digital (Agus Triyono, 2016).

Media Digital kini sudah menjadi media penting yang digunakan disetiap 
kalangan. Hal ini dapat dilihat dari bagaimana Indonesia menjadi pengguna Facebook terbesar ke dua di dunia. Media digital tumbuh pesat seiring dengan bertambahnya pengguna internet dikawasan asia khususnya Indonesia. Media digital bahkan kini sudah menjadi gaya hidup disetiap kalangan, di samping itu penggunaan media digital telah banyak membantu setiap orang dalam melakukan rutinitas, termasuk dalam berkomunikasi, baik dalam individu maupun dalam komunikasi massa. Jenis - jenis media digital yang sering digunakan saat ini yaitu : Youtube, Facebook, Twitter, Path, dan Instagram, yang di mana masing masing dari jenis media digital tersebut mempunyai fungsi yang hampir sama, yaitu berkomunikasi. Fungsi lain dari penggunaan media digital, yaitu : branding, sharing, promosi, dan marketing. Banyaknya kemudahan dan fungsi dalam penggunaan media digital, mendorong banyak perusahaan memanfaatkan fasilitas media digital sebagai sarana promosi, marketing, dan branding produk dan jasanya. Salah satu divisi di dalam perusahaan yang telah memanfaatkan kemudahan media digital untuk pekerjaanya adalah divisi Public Relations.

Digital Public Relations atau e-PR atau dapat disebut juga sebagai Cyber Public Relations merupakan konsep baru yang digunakan dalam manajemen PR. Dasrun Hidayat (2014:95) menyampaikan lahirnya era globalisasi teknologi yang sekarang ini sudah berkembang, maka secara tidak langsung juga mempengaruhi segala hal, termasuk cara kerja PR dan perkembangan perusahaan. Praktek Digital Public Relations (PR) merupakan salah satu bagian dari kegiatan hubungan masyarakat yang diadaptasi dari penggunaan teknologi informasi dan komunikasi bagi perusahaan. Oleh karena itu PR penting untuk menyesuaikan diri dengan perkembangan teknologi modern serba canggih, untuk berkerja lebih praktis dan cara kerja yang cepat juga dinamis. Hal tersebut yang harus diperhatikan setiap perusahaan untuk mulai melirik penggunaan internet sebagai komunikasi perusahaan dalam menyebarkan informasinya kepada pelanggan dan khalayak yang luas.

Menurut Bob J. Onggo (2004:1) pengertian inisiatif PR atau Public Relations yang menggunakan media internet sebagai sarana publikasinya, inisiatif PR ini di Indonesia lebih dikenal dengan istilah Cyber Public Relations. Namun dalam bukunya menggunakan istilah yang disingkat menjadi E-PR. Kalau diuraikan secara lebih spesifik E-PR adalah : 1) E adalah electronic. Elektronik di dalam E-PR sama seperti halnya huruf "e" sebelum kata mail atau commerce yang mengacu pada media elektronik internet. Berkaitan dengan penelitian yang dilakukan, elektronik disini diibaratkan sebagai digital; 2) P adalah publik. Publik disini mengacu bukan sekedar publik secara umum, namun pasar konsumen. Publik juga tidak hanya mengacu pada satu jenis pasar konsumen, namun pada berbagai pasar atau public audience; 3) $\mathrm{R}$ adalah relations. Relasi merupakan hubungan yang harus dipupuk antara pasar dan bisnis. Itu merupakan kunci pasar agar suatu bisnis berhasil. Menariknya, melalui media internet hubungan yang sifatnya one to-one dapat dibangun dalam waktu yang cepat kerena sifat internet yang interaktif. Hal ini berbeda dengan publik konvensional, yang dimana PRaktisi PR harus menjangkau mereka dengan sifat one-to-many.

Tools yang digunakan dalam strategi digital / cyber public relations untuk meningkatkan kepercayaan di mata publiknya antara lain: 1) Website Perusahaan. Situs resmi dibangun oleh perusahaan dan disesuaikan dengan kebutuhan publikasi informasi perusahaan, dengan adanya situs resmi perusahaan dapat memudahkan praktisi PR dalam menyajikan berbagai informasi terkait dengan perusahaan secara umum. 
Informasi tersebut dapat berupa profil perusahaan, berita terkini, katalog produk atau jasa, informasi mengenai potongan harga, bonus untuk konsumen dan lainnya, melalui hal tersebut dapat meningkatnya pemahaman mengenai perusahaan dibenak konsumen meningkat; 2) Publisitas Situs Pencari (Google/Yahoo). Situs pencari merupakan perangkat yang sangat umum digunakan oleh masyarakat dalam mencari referensi mengenai berbagai hal. Bentuk publisitas yang digunakan dalam situs pencarian bagi perusahaan ialah ketika hasil dari pencarian menunjukan potensi brand lebih mudah dilihat oleh masyarakat; 3) Press Release Online. Siaran pers merupakan media yang banyak digunakan dalam kegiatan kehumasan, karena melalui siaran pers informasi mengenai kegiatan perusahaan dapat disebarkan kepada publik secara lebih luas. Namun melalui penggunaan media digital proses pembetukan siaran pers jadi lebih efisien. Sehingga informasi yang telah dirangkum oleh praktisi PR akan dengan mudah dikirim melalui e-mail kemudian disunting dan langsung ditampilkan oleh media online; 4) Autoresponder pada email. Perangkat penjawab otomatis merupakan salah satu alat yang digunakan dalam kegiatan digital PR dalam meringankan perkerjaan. Perangkat penjawab otomatis akan mengirimkan pesan kepada pelanggan yang telah memberikan ulasan atau respon kepada perusahaan; 5) Kartu nama elektronik pada e-mail. Kartu nama elektronik merupakan kartu nama yang terletak pada bagian bawah e-mail, yang berisikan informasi mengenai nama, jabatan, serta nama perusahaan serta kontak. Penggunaan ini dapat memudahkan identitas pengirim pesan elektronik; 6) E-newsletter. Majalah online atau publikasi yang disusun oleh praktisi PR baik digunakan secara internal maupun eksternal untuk menghimpun berita yang berkaitan dengan kegiatan perusahaan, yang akan diunggah pada situs resmi perusahaan atau dikirim dalam bentuk tautan melalui pesan elektronik sehingga pihak internal maupun eksternal dapat mengunduhnya untuk mengetahui berita terbaru mengenai keberlangsungan perusahaan; 7) Mailing list (Forum pada website perusahaan). Publisitas digital Public Relations dalam meningkatkan brand awareness bagi pelanggan maupun calon pelanggan adalah dengan mengirim e-mail dengan penggunaan bahasa dan struktur kalimat yang benar untuk meningkatkan pemahaman konsumen mengenai perusahaan; 8) Forum. Penggunaan komunitas online atau dapat juga disebut dengan discussion group, online group, news group atau lainnya yang merupakan sekumpulan orang yang menggunakan media digital sebagai tempat untuk berdiskusi mengenai topik tertentu. Melalui forum ini praktisi PR dapat mengidentifikasi pesaing, tren terbaru, informasi yang lebih mendalam mengenai persepsi konsumen mengenai produk, dapat juga menjadi riset pasar sebelum meluncurkan produk baru. Termasuk didalamnya sosial media seperti facebook, twitter, instagram, blog dan lainnya.

$$
\text { Lebih lanjut Bob J. Onggo }
$$
(2004:5) menjelaskan beberapa peranan digital PR bagi perusahaan antara lain: 1) Jangkauan global. Melalui media digital yang terhubung dengan internet, jangkauan pesan yang akan disebarkan oleh perusahaan akan menjadi lebih luas jangkauannya. Bukan lagi hanya terbatas pada areal lokal maupun regional, namun melalui media digital pesan tersebut dapat menjangkau secara global; 2)Interaktif (komunikasi dua arah). Audiens yang terhubung melalui internet dapat memperoleh akses informasi digital selama 24 jam dalam sehari, sehingga informasi yang diperoleh dapat diakses kapan saja. Selain informasi yang selalu tersedia penggunaan media digital akan memudahkan audiens untuk memperoleh informasi yang cepat dengan tampilan yang interaktif. Sehingga memungkinkan terjadinya komunikasi dua arah antara perusahaan dengan publik tujuan utama dari kegiatan digital Public Relations; 3) 
Biaya efesien. Biaya yang dikeluarkan dalam pemanfaatan digital Public Relations jauh lebih murah dibandingkan dengan kegiatan PR yang secara konvensional. praktisi PR hanya perlu menyesuaikan jenis media digital mana yang akan digunakan dalam menampilkan pesan perusahaannya; 4) Memelihara reputasi. Melalui kehadiran perusahaan dalam dunia digital dapat memudahkan citra yang akan dibangun dihadapan publik. Kehadiran PR dalam berpartisipasi dalam topik-topik tertentu akan memberikan citra tertentu pada benak publik begitu juga dengan informasi yang diberikan secara kesinambungan akan membantu reputasi yang dibangun akan terpelihara dengan baik; 5) Menjalin hubungan. Interaksi yang dibangun pada media digital dapat menciptakan hubungan berkesinambungan antara perusahaan dengan publiknya atau bahkan stakeholder-nya. Hal ini dapat dilakukan apabila perusahaan aktif dalam membalas setiap respon yang diberikan audiens pada media digital.

Fungsi digital PR adalah untuk memberikan infromasi seluas dan secepat mungkin kepada publik. Informasi ini terkait dengan perkembangan perusahaan atau informasi produk yang sangat penting diketahui oleh publik (Hidayat, 2014:108). Digital PR dalam penerapannya diharpkan dapat memberikan manfaat kepada publiknya.

Penelitian mengenai Digital PR sudah banyak dilakukan seperti yang dilakukan oleh Agus Triyono (2016) yang berjudul Inovasi Digital Public Relations pada Perguruan Tinggi Swasta di kota Semarang dalam meningkatkan citra. Hasil penelitian menunjukkan Media sosial seperti facebook, instagram,twitter, path, line menjadi terobosan yang paling banyak digunakan oleh setiap perguruan tinggi dalam menjalin komunikasi dengan masyarakat luas. Dan facebook merupakan media yang paling banyak diakses oleh tim humas dalam rangka menyampaikan informasi, sehingga mampu meningkatkan reputasi dan citra perguruan tinggi yang bersangkutan.

Penelitian berikutnya yang dilakukan oleh Arief Syahputra dan M.E. Fuady (2019) yang berjudul Strategi Digital Public Relations pada INFOBDG, hasil penelitian menunjukkan strategi digital Public Relations yang digunakan Infobdg dalam mempertahankan eksistensi corporate image menggunakan media twitter telah berhasil memberikan pengaruh yang besar sehingga dengan hal itu eksistensi Infobdg di media jejaring sosial masih tetap ada dan terjaga.

Dalam penelitian yang dilakukan oleh Trisnani (2018) yang berjudul implementasi e-government public relations sebagai peningkatan pelayanan informasi publik, dilingkungan pemerintah daerah di jawa timur dan nusa tenggara barat hasil penelitian menunjukkan sebagian besar ASN memahami pelayanan informasi publik secara online, ASN secara individu sebagian besar menggunakan media sosial, akun media sosial yang sering digunakan untuk pelayanan informasi publik facebook.ASN sebagian besar menggunakan Instant Messaging, aplikasi yang sering digunakan untuk pelayanan publik WhatsApp, informasi yang dibutuhkan masyarakat informasi pekerjaan. Sikap ASN terhadap penerapan integrasi jaringan sebagian besar sangat setuju. Hasil penelitian ini, termasuk kategori positif, karena ASN Public relations memiliki Pemahaman yang baik, kecenderungan dan perilaku setuju menggunakan TIK dan Media sosial serta penerapan integrasi jaringan. Dengan demikian ASN mendukung terhadap integrasi jaringan

Label Demajors Independent Music Industry (DIMI) atau biasa disebut demajors ini berbeda dengan label rekaman musik popular di Indonesia. Demajors mengkategorikan bahwa mereka adalah label musik sidestream yang mana lebih bermain ke sisi idealisme dari sang musisi, Demajors mempunyai tugas utama mendistribusikan dan menyebarluaskan 
rilisan - rilisan mereka tanpa batasan jenis musik yang dihasilkan dan campur tangan dalam meramu musik. Musik - musik yang dirilis demajors pun tidak sembarangan, karena mereka tetap mengutamaan kualitas. (www.demajors.com). Pada tahun 2003 - 2004 ketika record store didirikan oleh Demajors keadaan berubah, konsumen utama demajors perlahan meninggalkan piringan hitam dan beralih ke perangkat lunak digital dan format $m p 3$ dalam berkarya, karena bisnis record label mengalami penurunan maka Label Musik Demajors memutuskan untuk menutup record store dulu. Pada tahun 2012 Label Musik Demajors meluncurkan distribusi Online melalui www.demjors.com dan meluncurkan pelayanan digital download.(https://swa.co.id/swa/PRofile/P Rofile-entre $p r e n e u r /$ kiprah-demajors-diblantika-musik-indonesia, by Rangga Wiraspati - March 21, 2013)

Menjadi menarik bagi penulis untuk mengangkat sepak terjang label musik Demajors dalam upaya mempublikasikan rilisan album digital dibawah naungannya mengingat bahwa demajors memiliki karakter yang berbeda dengan label musik popular kebanyakan. Demajors memiliki karakter musik alternatif yang tidak kalah bila kita bicarakan tentang kualitas dan keunikannya. Tidak mudah bagi Demajors dalam mengembangkan industri musik sidestream tanah air, mengingat mayoritas media massa di Indonesia masih sangat terbatas dalam mengolah informasi tentang geliat industri musik indie atau independen. Penulis juga tertarik ingin mengetahui bagaimana Label musik Demajors akhirnya memutuskan mengambil konsep lain untuk masuk ke dalam industri musik Indonesia, dengan mendirikan record label dan distribusi Demajors. Label Musik Demajors hingga kini masih dapat menembus pasar industri musik mainstream dan Poduktif dengan pendistribusian album rilisannya walaupun begitu banyak label musik Mainstream yang berkembang di Indonesia. Tingginya gairah kreatifitas musik sidestream di
Indonesia, menjadi sebuah tantangan besar tentunya bagi divisi new media dan divisi Promotions \& media relations pada label musik Demajors.

Berkaitan dengan kegiatan Implementasi Digital PR yang dilakukan oleh label musik Demajors yang menjadi topik penelitian ini maka diperlukan pula pengetahuan mengenai komunikasi yang menggunakan media elektronik, yang secara teoritis dijelaskan dala poin mengenai Computer-Mediated Communication.

Menurut Wood dan Smith (2005:4) dalam era teknologi informasi hari ini, mode komunikasi yang kita jalani telah diperantarai oleh internet dan telah bergerak secara cepat menuju apa yang disebut dengan Computer Mediated Communication (CMC) atau komunikasi yang di mediasi oleh komputer. Dalam kenoteks ini, Computer Mediated Communication (CMC) dipandang sebagai intergrasi teknologi komputer dengan kehidupan sehari - hari.

Computer-Mediated Communication (CMC) adalah istilah yang digunakan untuk melakukan komuniasi antar dua orang atau lebih yang dapat saling berinteraksi melalui komputer yang berbeda, Menurut Thurow, Angel, Tomic (2004:15)

Computer-Mediated Commuication adalah proses manusia berkomunikasi via komputer, dengan melibatkan seseorang, dalam situasi konteks tertentu, dengan terlibat dalam proses untuk membentuk media sebagai tujuannya.

Sementara istilah secara tradisional disebut dengan komunikasi yang terjadi melalui format komputer (misalnya, pesan instan, email, chat room, forum online, layanan jaringan sosial) juga telah diterapkan pada bentuk - bentuk lain dari interaksi berbasis teks seperti pesan teks (Thurow, Angel, Tomic 2004:31).

CMC berada pada batasan model komunikasi interpersonal (one to one), komunikasi massa (one to many), dan komputerisasi (many to one). Model lain 
atau bentuk keempat ialah many to many, yaitu setiap orang bisa menjadi sender atau receiver, setiap orang data menerima atau mengirim pesan yang bersifat personal atau massal. Informasi dapat diberikan oleh banyak orang dan diakses oleh banyak orang juga disimpan untuk dibuka atau dipilih kembali secara individual (Burnett dan David Marshall 2003:48).

Teori ini dipilih mengingat aktivitas kegiatan Digital PR sebagaimana namanya, berbasis pada media baru yakni media digital dengan format - format kontennya yang diakses melalui komputer.

Sehubungan dengan analisis media compute dalam penelitian ini diistilahkan sebagai Computer Mediated Communication, Maka Menurut Dermawan (2012:38) terdapat dimensi Computer Mediated Communication (CMC) yang dapat ditinjau dari beberapa hal dibawah ini, yaitu: 1) Dimensi Accsesibility (Daya Jangkau/Akses Informasi). Dimensi ini mengindikasikan bahwa proses komunikasi yang bertujuan menyampaikan informasi melalui computer mediated communication mampu mencapai akses atau jangkauan yang luas; 2) Dimensi Speed (Kecepatan Informasi). Dimensi ini menginidkasikan bahwa proses penyampaian informasi oleh sender melalui CMC mampu menunjukan kecepatan dalam penerimaanya oleh receiver; 3) Dimensi Amount (Jumlah/Kuantitas Informasi). Dimensi ini menunjukan bahwa infromasi yang disampaikan oelh sender kepada receiver melalui $\mathrm{CMC}$ mampu memenuhi kebutuhan jumlah informasi yang diperlukan; 4) Dimensi Cognitive Effectiveness (Keefektifan memperoleh pengetahuan). Dimensi ini menunjukan bahwa infromasi yang disampaikan oleh sender ke receiver melalui CMC mampu menanamkan dan memperkaya pengetahuan secara efektif mengenai informasi yang dibutuhkan; 5) Dimensi Relevance (Kesesuaian Informasi). Dimensi ini menunjukan bahwa informasi yang disampaikan oleh sender ke receiver melalui CMC mampu memenuhi tingkat kesesuain dengan kebutuhan target; 6) Dimensi Motivating (Dari Informasi). Dimensi ini menunjukan bahwa informasi yang disampaikan oleh sender ke receiver melalui CMC mampu menumbuhkan motivasi untuk memahami dan menerapkannya.

\section{METODOLOGI PENELITIAN Paradigma Penelitian}

Penelitian ini menggunakan paradigma konstruktivisme. Peneliti menggunakan paradigma ini karena berorientasi untuk menemukan pengertian atau pemaknaan atas sebuah hal serta memberikan penjelasannya menggunakan nalar sendiri, dalam hal ini adalah implementasi digital $P R$ pada label musik Demajors dalam mempublikasikan album.

Aliran konstruktivisme menyatakan bahwa realitas itu ada dalam beragam bentuk konstruksi mental yang didasarkan pada oengalaman sosial, bersifat local dan spesifik, serta tergantung pada pihak yang melakukannya. Oleh karena itu, sebuah realitas yang diamati oleh peneliti tidak bisa digeneralisasikan kepada semua orang. Dalam paradigma, hubungan antara pengamat dan objek merupakan satu kesatuan, subjektif dan merupakan hasil perpaduan interaksi antar keduanya (Moleong, 2010:70).

Peneliti mendasari penelitian menggunakan paradigma ini dengan tujuan untuk mengungkap kegiatan digital $P R$ pada label musik Demajors dalam mempublikasikan album secara komperhensif dan mendalam.

\section{Pendekatan Penelitian}

Dalam penelitian ini penliti menggunakan penelitian kualitatif. Penelitian kualitatif adalah metode penelitian yang digunakan untuk meneliti pada kondisi obyek yang alamiah, dimana peneliti adalah sebagai instrument kunci, teknik pengumpulan data dilakukan secara triangulasi (gabungan), analisis data bersifat induktif, dan hasil penelitian 
kualitatif lebih menekankan makna daripada generalisasi (Sugiyono, 2014:1).

Dalam penelitian ini penulis memakai pendekatan deskriptif kualitatif yang bertujuan untuk mengenal, mendapatkan, serta memberikan gambaran atau paradigma mengenai suatu gejala. Penelitian ini berusaha untuk memperlihatkan gambaran tentang implementasi Digital $P R$ label musik demajors dalam mempublikasikan album baru yang diharapkan mampu menghasilkan suatu uraian, mendalam tentang ucapan, tulisan, dan tingkah laku yang dapat diamati dari suatu individu, kelompok, masyarakat, organisasi tertentu dalam suatu konteks setting tertentu yang dikaji dari sudut pandang yang utuh dan komperhensil.

\section{Metode Penelitian}

Metode yang digunakan dalam penelitian ini adalah studi kasus. Sebuah studi kasus memberikan deskripsi tentang individu. Individu ini biasanya adalah orang, tapi biasa juga sebuah tempat seperti perusahaan, sekolah, dan lingkungan sekitar. Sebuah observasi naturalistic kadang juga disebut dengan studi kasus (Cozby, 2009:188). Menurut Yin (2017:8) Studi kasus merupakan penyelidikan yang bersifat empiris yang menginvestigasi sebuah fenomena dalam kehidupan nyata.

Metode yang digunakan dalam penelitian ini studi kasus, karena peneliti berusaha melakukan eksplorasi mendalam dan memberikan penjelasan yang komperhensif mengenai suatu objek, untuk mengetahui bagaimana implementasi digital $P R$ label musik Demajors dalam mempublikasikan album digital.

\section{Teknik Keabsahan Data}

Dalam penelitian ini peneliti menggunakan Triangulasi Sumber dalam pengujian keabsahan data. Triangulasi sumber dilakukan dengan menguji kredibilitas data dilakukan dengan cara mengecek data yang telah diperoleh melalui beberapa sumber. Data yang diperoleh kemudian dideskripsikan dan dikategorisasikan sesuai dengan apa yang diperoleh dari berbagai sumber tersebut. Peneliti akan melakukan pemilahan data yang sama dan data yang bebeda untuk dianalisis lebih lanjut.

$$
\text { Triangulasi dalam pengujian }
$$

kredibilitas ini diartikan sebagai pengecekan data dari berbagai sumber dan berbagai cara. Dengan demikian rencana pemeriksaan keabsahan data yang digunakan dalam penelitian ini melalui triangulasi sumber. Hal itu dapat dicapai dengan : 1) Membandingkan data hasil pengamatan dengan data hasil wawancara yang dilakukan kepada key informan (pihak Head Promotion label musik Demajors) I Gede Oka Wibawa; 2) Membandingkan data hasil pengamatan atas key informan dari pihak label musik demajors dengan infroman yaitu divisi New Media yang melakukan strategi publikasi kepada artis sebelum mempublikasikannya kepada khalayak atau publik.

Dalam penelitian ini peneliti menggunakan triangulasi, yang berarti penliti dapat me-rechek temuannya dengan jalan membandingkannya dengan berbagai sumber, metode atau teori.

\section{HASIL PENELITIAN DAN PEMBAHASAN Hasil penelitian}

Setelah mendapatkan hasil wawancara yang dilakukan terhadap subjek penelitian, maka penulis mendapatkan fakta - fakta di lapangan mengenai implementasi divisi Promotion $\&$ media relations dan divisi new media label musik Demajors dalam mempublikasikan rilisan album digital. Penulis mengembangkan hasil wawancara yang telah di dapat ke dalam sebuah analisis, berikut hasil analisis wawancara terkait:

$$
\text { Tahap pertama dalam }
$$
mempublikasikan rilisan album digital divisi Promotion \& media relations label 
musik Demajors yaitu dengan memahami dan mencari tahu karakter dari artis atau musisi yang akan membuat rilisan album melalui label musik Demajors. Pemahaman mengenai genre musik, karakter pribadi musisi, target media, target khalayak sampai dengan strategi yang sesuai dengan album yang akan dirilis.

Proses awal pemahaman karakter adalah langkah utama sebelum akhirnya divisi Promotion \& media relations dan divisi new media berdiskusi dengan musisi untuk menentukan program - program publikasi seperti apa yang cocok dengan musisi yang akan merilis album digitalnya. Aggregator mempunyai fungsi mendistribusikan materi rilisan album ke platform digital, aggregator tersebut mempunyai file khusus bernama tracker Promotion. Label musik Demajors mempunyai fungsi yaitu sebagai konsultan untuk membantu musisi mengisi form trakcer Promotion yang berisi semua kegiatan atau program - program publikasi rilisan album yang akan di kirim ke aggregator yang nantinya diajukan ke platform digital untuk menang pitching.

Setelah memahami langkah awal yang dilakukan label musik Demajors dalam mempublikasikan rilisan album digital, juga menyiapkan materi publikasi rilisan album digital yang dikerjakan oleh divisi Promotion \& media relations di ranah media Online.

Label musik Demajors membuat press release hanya untuk rekan rekan media, supaya penyebaran pesan dapat disebarluaskan oleh rekan media yang memang tujuan utamanya agar masyarakat mengetahui rilisan album baru tersebut. press release yang dibuat oleh Demajors berupa informasi mengenai perilisan album mengandung $5 \mathrm{~W}+1 \mathrm{H}$ atau pihak divisi Promotion \& media relations yang akan mewawancarai musisi tersebut, kemudian dicantumkan beberapa foto dari band yang akan merilis albumnya. Jika masyarakat telah mengetahui informasi tersebut dari media massa, maka masyarakat akan mencari tahu album tersebut melalui website resmi Demajors dan mendengarkan langsung album tersebut melalui preview berupa audio yang dapat diputar. Pernyataan tersebut juga di bahas oleh divisi new media terkait press release yang disebarkan ke media online.

Pengiriman press release kepada rekan media adalah sebagai bahan publikasi terkait materi rilisan album digital baru. Informasi publikasi tersebut cukup berguna karena membuat masyarakat melihat dan mencari tau informasi yang lebih detail mengenai rilisan album digital tersebut. Label musik Demajors menyerahkan semua informasi tentang musisi terkait kepada media massa atau media online.

Divisi new media juga memaparkan beberapa kendala yang di alami oleh label musik demajors dalam mempublikasi rilisan album digital kepada media. Adanya kendala dalam mempublikasikan rilisan album digital tersebut masih dapat ditangani oleh divisi Promotion \& media relations dan divisi new media, namun kendala sering kali terjadi jika label musik Demajors akan melakukan pendekatan media yang sesuai dengan karakter musisi dan album yang akan dirilis. Jadi memang label musik Demajors akan memilih lagi media mana yang sesuai dengan materi rilisan album baru tersebut. Dengan tujuan utama memudahkan masyarakat untuk menikmati rilisan album digital tersebut.
Label musik
Demajors

mengimplementasikan program - program publikasi dengan membangun komunikasi yang baik dengan berbagai pihak yaitu pihak media dan pihak masyarakat. Demajors juga mengimplementasikan program dengan cara yang berbeda ke setiap sosial media yang mempublikasikan materi publikasi rilisan album digital, adanya kesesuaian tersebut diyakini label musik Demajors dapat membangun suatu kepercayaan dan ketertertarikan tersendiri bagi setiap khalayak dan media. 
Label musik Demajors sangat memaksimalkan hubungan yang baik dengan media, musisi, masyarakat, maupun aggregator dalam usaha mempublikasikan rilisan album digital karena pada dasarnya label musik Demajors sangat terbuka bagi musisi maupun masyarakat yang menikmati hasil dari rilisan album tersebut. Demajors menganggap bahwa semua pihak yang berkerjasama dalam mempublikasi album digital adalah keluarga. Masing - masing pihak harus dapat saling mendukung dan berhubungan satu sama lain, betapa pentingnya proses publikasi dan komunikasi dari masing - masing pihak agar tujuan utama dapat tercapai. Suatu kepercayaan yang dibangun dengan baik oleh label musik Demajors diyakini juga dapat membawa hasil yang positif dari berbagai pihak.

Dalam membangun sebuah publisitas, Demajors mempunyai beberapa platform yang menyebarkan informasi terkait publikasi album digital melalui website dan media sosial Demajors juga membangun publisitas melalui youtube, yang sekarang sedang berkembang masyarakat di Indonesia. Publikasi melalui youtube adalah faktor utama yang menarik masyarakat dalam mengetahui rilisan album digital tersebut.

Hal lain yang dilakukan divisi Promotion \& media relations dalam membangun kepercayaan masyarakat untuk menikmati rilisan album digital, yaitu menyiapkan Autoresponder pada email atau website.

Label musik Demajors mempunyai suatu forum diskusi di ranah media sosial yaitu facebook group hanya sebagai penyebarluasan publikasi rilisan album digital karena sifat media sosial yang dapat menyebarkan informasi secara cepat. Demajors tidak mengukur keinginan pangsa pasar dengan adanya forum ini, karena Demajors adalah independent musik industri, Demajors berusaha untuk meratakan dan menggali idealisme musisi dalam setiap rilisan album yang ada.
Divisi new media mengungkapkan adanya kelebihan dan kesulitan dalam menjalin kerjasama dengan digital platform, yaitu dalam mengajukan materi rilisan album digitalnya ke digital platform karena setiap digital platform yang ada masing - masing mempunyai kriteria tersendiri dalam menerima materi rilisan album yang akan dipublikasikan di digital platformnya. Jadi label musik Demajors tidak pernah tahu seberapa besar kemungkinan rilisan albumnya bisa diterima dan dipublikasikan di digital platform.

Setelah semua rangkaian materi publikasi rilisan album digital telah terlaksana, dimulai dari berdiskusi tahap awal, menentukan program yang sesuai dengan karakter musisi itu sendiri, dan menyebarluaskan rilisan album keberbagai media, divisi Promotion dan media relations melakukan sebuah evaluasi terkait evaluasi program - program yang sudah sesuai dengan apa yang dibutuhkan musisi, tim Promotions \& media relations, jika ada sesuatu kesulitan yang kami hadapi, kami sangat terbuka satu sama lain, dan akan mencari solusi dari kesulitan tersebut. Biasanya kami akan saling memback up jika ada miss communication kepada pihak- pihak media yang akan mempublikasikan rilisan album digital dan kita hanya tinggal menunggu feedbacknya saja.

\section{Pembahasan Hasil Penelitian}

Peneliti mengaitkan usaha label musik Demajors dalam meningkatkan kepercayaan dimata penikmat musik, konsumen atau masyarakat dengan konsep teori Tools Digital PR yang dikemukakan oleh Bob J Onggo, seperti Tools digital PR yang digunakan juga oleh label musik Demajors sebagai berikut: 1) Website Perusahaan. Situs resmi dibangun oleh perusahaan dan disesuaikan dengan kebutuhan publikasi informasi perusahaan, dengan adanya website perusahaan dapat memudahkan praktisi $P R$ dalam menyajikan berbagai informasi publikasi. 
Head Promotion \& media relations dan divisi new media mengungkap bahwa website resmi Demajors tidak mencantumkan press release yang dibuat oleh pihak demajors karena press release diserahkan seluruhnya kepada rekan rekan media yang membantu mempublikasikan rilisan album digital dengan mengkreasikan ide kreatif dari media tersebut. Demajors mempunyai strategi lain untuk mempublikasikan rilisan album digital dengan cara mencantumkan teaser album selama 30 - 40 detik yang dapat di play dan didengarkan langsung oleh masyarakat dengan menambahkan $10-15$ kalimat informasi mengenai album tersebut. Cara itu mampu mempertahankan kepercayaan dari masyarakat dan membuat masyarakat ingin mengetahui lebih lanjut mengenai album tersebut; 2) Publisitas Situs Pencari . Situs pencari merupakan perangkat yang sangat umum digunakan oleh masyarakat dalam mencari referensi mengenai berbagai hal. Label musik Demajors telah menyebarkan seluruh informasi materi rilisan album digital melalui press release yang diberikan kepada rekan media online. Demajors menggunakan beberapa media juga untuk membantu publikasi rilisan album digital seperti youtube, Instagram, facebook, dan twitter. Ketika masyarakat ingin mengetahui informasi mengenai rilisan album digital secara lebih lanjut melalui google hanya dengan menulis keyword keyword yang mereka inginkan atau bisa langsung membuka website resmi milik Demajors. Kemudian label musik Demajors juga berusaha membangun publisitas di media Youtube dengan memuat music video album terkait, Demajors sudah menjadi konten ID Youtube yang berarti demajors mempunyai sebuah kebijakan khusus untuk memproteksi karya dari musisi yang merilis album digitalnya. Media youtube juga diyakini oleh label musik Demajors memberikan efek positif bagi perusahaan karena dari media tersebut penyebaran informasi mengenai rilisan album digital lebih cepat meningkat dan dapat diukur secara langsung dengan melihat subscriber dan viewers; 3) Press Release Online. Siaran pers merupakan media yang banyak digunakan dalam kegiatan publikasi, karena melalui siaran pers informasi mengenai kegiatan perusahaan dapat disebarkan kepada publik secara lebih luas. Label musik Demajors membuat press release dengan teknik $5 \mathrm{~W}+1 \mathrm{H}$, biasanya isi press release tersebut berupa informasi mengenai perilisan album maupun informasi lainnya terkait musisi yang akan merilis albumnya, kemudian Demajors juga memuat foto dan flayer digital seperti flayer di Spotify atau dapat juga pihak label musik demajors khususnya divis Promotion \& media relations yang mewawancarai musisi secara langsung; 4) Autoresponder pada E-Mail. Dalam hal ini label musik Demajors mempunyai strategi lain dalam mengaplikasikannya, Demajors berusaha untuk selalu membalas pesan yang sampai secara manual. Head Promotion \& media relations label musik Demajors mengungkapkan dengan menerapkan strategi seperti itu Demajors dapat mempertahankan kepercayaan masyarakat dan lebih mendekatkan hubungan perusahaan dengan media dan masyarakat hingga terjalin komunikasi yang baik; 5) Kartu Nama Elektronik pada E-Mail. Label musik demajors selalu mencantumkan alamat media sosial dan email di website resmi demajors, begitu juga sebaliknya di media sosial Demajors juga mencantumkan website resmi dan nomer telefon yang dapat dihubungi dengan tujuan siapapun yang akan bertanya dan ingin mengetahui informasi lebih lanjut dari label musik Demajors masyarakat akan mudah menghubungi secara langsung agar terjadinya komunikasi yang baik; 6) E-Newsletter. Majalah online yang disusun oleh praktisi $P R$ baik digunakan secara internal maupun eksternal untuk menghimpun berita yang berkaitan dengan perusahaan. Setelah Label musik Demajors mengevaluasi proses publikasi rilisan album digital untuk 
saat ini majalah online yang dibuat oleh Demajors tidak dilanjutkan karena mendapatkan respon yang baik dari masyarakat. Maka label musik Demajors menjalankan program lain guna mempublikasi rilisan album digital yang lebih mendapatkan respon positif dari masyarakat atau penikmat music; 7) Mailing list. Publisitas digital $P R$ dalam meningkatkan kepercayaan dimata masyarakat dengan menggunakan cara mengirim e-mail kepada rekan media dan masyarakat. Label musik Demajors berusaha secara manual untuk membalas semua pesan yang masuk ke e-mail dengan penggunaan bahasa dan struktur kalimat yang benar serta informatif untuk meningkatkan pemahaman masyarakat dalam menerima pesan; 8) Forum. Penggunaan komunitas online atau dapat juga disebut dengan discussion group, online group, news group atau lainnya yang merupakan sekumpulan orang yang menggunakan media digital sebagai tempat untuk berdiskusi mengenai topik tertentu. Label musik Demajors mempunyai forum online tersebut di media sosial yaitu Facebook Fanpage. Dalam Facebook Fanpage tersebut terdapat sekumpulan orang yang mempunyai selera yang sama mengenai suatu musik yang dirilis oleh label musik Demajors kemudian salah satu strategi label musik Demajors adalah mempublikasikan informasi tentang rilisan album digital agar masyarakat dapat mengetahui secara cepat, label musik Demajors berusaha sebisa mungkin untuk dapat mempublikasi rilisan album digital ke berbagai macam lapisan masyarakat.

Dengan tools digital $P R$ yang telah diterapkan oleh label musik Demajors menunjukkan bahwa label musik Demajors dapat bersaing dengan label musik mainstream di Indonesia lainnya. Terbukti dengan adanya rilisan album yang dikeluarkan oleh Demajors minimal 2 buah album digital setiap bulannya. Label musik Demajors sangat membutuhkan kegiatan publikasi untuk memperkenalkan kepada khalayak bahwa musisi - musisi yang merilis album di Demajors mempunyai suatu keunikan dan karakter atau aliran musik yang sangat luar biasa. Oleh karena itu, label musik Demajors sangat membutuhkan media lain dalam menyebarkan publikasi mengenai rilisan albumnya.

Divisi Promotion \& media relations, I Gede Bagus Oka dan divisi new media, Aldila Karina Putri label musik Demajors mengemukakan bahwa kegiatan publikasi rilisan album digital yang dilakukan oleh Demajors pada hakikatnya sama dengan label musik mainstream di Indonesia, namun mereka mengungkapkan bahwa label musik Demajors mempunyai kekuatan tersendiri dalam pubikasi rilisan album tersebut dengan cara menonjolkan karakter yang sesuai dari musisi yang akan merilis albumnya. I Gede Bagus Oka mengungkapkan bahwa Divisi Promotion \& media relations label musik Demajors mempunyai perbedaan dengan Divisi $\mathrm{New}$ Media, yaitu didalam divisi Promotion dan media relations hanya fokus untuk menyiapkan segala timeline program publikasi seperti membuat press release, teaser rilisan album untuk di website sedangkan Divisi New Media label musik Demajors lebih memfokuskan persiapan rilisan album melalui digital platrofm dan media sosial.

\section{SIMPULAN \\ Simpulan}

Dari proses penelitian yang telah dilakukan oleh penulis terhadap implementasi digital $P R$ dalam mempublikasi rilisan album label musik Demajors, penulis menyimpulkan bahwa dalam penelitian ini ditinjau berdasarkan pelaksanaan kegiatan publikasi di media digital (online) dan penggunaan tools digital $P R$ dimana label musik demajors khususnya divisi Promotion \& media relations dan divisi new media telah melaksanakan tugas dan tanggung jawabnya secara baik dan efektif. Divisi Promotion \& media relations dan divisi new media label musik Demajors telah 
melakukan berbagai usahanya untuk mempublikasikan rilisan album digital dengan menggunakan media - media digital untuk memudahkan penyebaran informasi kepada khalayak seluas luasnya, supaya mereka menyadari bahwa masih ada musik - musik yang berkualitas dengan refrensi eksplorasi luar biasa yang patut di gali dan mendapatkan tempat yang layak di hati masyarakat.

Secara struktural label musik Demajors tidak jauh berbeda dengan label musik kebanyakan. Mereka memiliki struktur perusahaan dengan tugas dan tanggung jawab masing - masing jabatan selayaknya perusahaan biasa. Yang berbeda adalah dimana setiap proses yang ada mereka berusaha untuk saling mendalami suatu karakter musisi yang akan merilis albumnya di label musik Demajors agar setiap tim yang nantinya akan berkerja sama lebih mengerti dan dapat menyesuaikan program publikasi dengan karakter musisi tersebut. Dengan kebebasan berkreasi yang Demajors yakini, mereka memiliki visi dan misi untuk memajukan industri musik tanah air dengan menggali suatu idealisme dan keunikan dari karya musisi dengan karakter dan rasa musik yang berbeda ke khalayak luas.

\section{DAFTAR PUSTAKA}

Agus Triyono (2016). Jurnal Ilmiah Komunikasi |MAKNA Vol. 6 no. 2, Agustus 2015-Januari 2016. Diakses melalui jurnal.unissula.ac.id/index.php /makna/article/view/2786/2047 pada tanggal 26 Mei 2019

Arief Syahputra dan M.E. Fuady (2019). Strategi Digital Public Relations pada INFOBDG (Studi Kasus Mengenai Strategi Digital Public Relations pada InfoBDG dalam Mempertahankan Eksistensi Corporate Image). Prosiding Hubungan Masyarakat (SPESIA). Diakses melalui

http://karyailmiah.unisba.ac.id/index.php/h umas/article/view/16806/xml pada tanggal 30 Juni 2019
Cozby. C. Paul (2009) Methods in behavioral research. Boston : McGrawHill Higher Education

Dermawan, Deni. 2012. Pendidikan Teknologi Informasi dan Komunikasi: Teori dan Aplikasi. Bandung: PT. Remaja Rosdakarya.

Hidayat, Dasrun. 2014. Media Public Relations: Pendekatan Studi Kasus Cyber Public Relations Sebagai Media Kerja PR Digital. Yogyakarta: Graha Ilmu.

Ifan Kurnia Afandia, Ridi Ferdiana (2014) Universitas Diponegoro. Musik dan Denyut Jantung Pada Era Digital.

Moleong, Lexy J. 2010. Metodologi Penelitian Kualitatif Edisi Revisi. Bandung: PT Remaja Rodakrya.

Onggo, Bob Julius. 2004. Cyber Public Relations. Jakarta: Elex Media Komputindo.

Sugiyono. 2014. Memahami Penelitian Kualitatif. Bandung: CV Alfabeta.

Thurlow, Crispin. Laura Angel. Alice Tomic. 2004. Computer Mediated Communication. United Kingdom: Sage Publications.

Trisnani (2018). Implementasi egovernment public relations sebagai peningkatan pelayanan informasi publik, dilingkungan pemerintah daerah di jawa timur dan nusa tenggara barat. Jurnal Komunikasi, Media dan Informatika, Vol. 7 No. 3 /November 2018 diakses melalui https://jurnal.kominfo.go.id/index.php/ko munika/ pada tanggal 1 Juli 2019

Wood, Andrew F. Dan Matthew J. Smith. 2005. Online Communication: Linking Technology, Identity and Culture. New Jersey: Larence Erlbaum Associates Yin, Robert K. 2017. Case Study Research and Applications: Design and Methods. Sixth Edition. California: Sage Publications.

\section{Lain - lain :}

www.demajors.com

https://swa.co.id/swa/PRofile/PRofileentre $P R$ eneur/kiPRah-demajors-di-

blantika-musik-indonesia, by Rangga

Wiraspati - March 21, 2013 